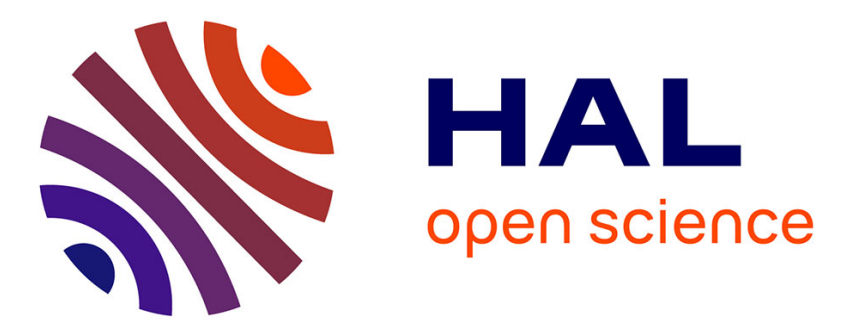

\title{
Sclerochronological records and daily microgrowth of the Peruvian scallop (Argopecten purpuratus, Lamarck, 1819) related to environmental conditions in Paracas Bay, Pisco, Peru
}

Arturo Aguirre-Velarde, Jonathan Flye-Sainte-Marie, Jaime Mendo, Fred Jean

\section{To cite this version:}

Arturo Aguirre-Velarde, Jonathan Flye-Sainte-Marie, Jaime Mendo, Fred Jean. Sclerochronological records and daily microgrowth of the Peruvian scallop (Argopecten purpuratus, Lamarck, 1819) related to environmental conditions in Paracas Bay, Pisco, Peru. Journal of Sea Research (JSR), 2015, 99, pp.1-8. 10.1016/j.seares.2015.01.002 . hal-01145400

\author{
HAL Id: hal-01145400 \\ https://hal.univ-brest.fr/hal-01145400
}

Submitted on 24 Apr 2015

HAL is a multi-disciplinary open access archive for the deposit and dissemination of scientific research documents, whether they are published or not. The documents may come from teaching and research institutions in France or abroad, or from public or private research centers.
L'archive ouverte pluridisciplinaire HAL, est destinée au dépôt et à la diffusion de documents scientifiques de niveau recherche, publiés ou non, émanant des établissements d'enseignement et de recherche français ou étrangers, des laboratoires publics ou privés. 


\title{
Sclerochronological records and daily microgrowth of the Peruvian scallop (Argopecten purpuratus, Lamarck, 1819) related to environmental conditions in Paracas Bay, Pisco, Peru
}

\author{
Arturo Aguirre Velarde ${ }^{\mathrm{a}, \mathrm{b}}$, Jonathan Flye-Sainte-Marie ${ }^{\mathrm{a}, *}$, Jaime Mendo ${ }^{\mathrm{b}}$, Fred Jean ${ }^{\mathrm{a}}$ \\ ${ }^{a}$ Université de Bretagne Occidentale; CNRS/UBO/IRD/Ifremer UMR 6539 Lemar, IUEM, Rue Dumont d'Urville, 29280 Plouzané, France \\ ${ }^{b}$ Facultad de Pesquería, Universidad Nacional Agraria La Molina, Av. La Molina s/n, La Molina, Lima, Perú
}

\begin{abstract}
We investigated the rhythm of micro-striae formation in the shell of Argopecten purpuratus and environmental influence on micro-growth increments by monitoring growth over a 98-day period between April and July 2007 under bottom and suspended culture ( $2 \mathrm{~m}$ above the bottom) rearing conditions. The transfer of individuals to the study site induced the formation of a notable growth mark that allowed us to count the number of micro-striae formed between transfer and sampling dates. Micro-striae counts showed a deposition rate of one stria per day independent of rearing condition. This result allowed us to analyse the relationships between growth increments and environmental conditions. We therefore examined the deviations between observed growth rates and growth rates predicted from a Von Bertalanffy growth function. Cross-correlation analysis revealed significant correlations, without time-lag, between these deviations and both particulate organic carbon and nitrogen concentrations in the bottom treatment. Additionally, we observed negative correlations with temperature and current speed at this depth with time-lags of 1 and 10 days respectively. In the suspended treatment, we observed a significant negative correlation with temperature, only with a 12-day lagtime. Our results show that growth response to environmental variability is not always instantaneous. This delay can be explained by the time delay over which metabolic processes need to be performed (e.g. digestion, use/movements of reserves, growth, reproduction). Further modeling studies could help to better understand these processes.
\end{abstract}

Keywords: Argopecten purpuratus growth, shell microgrowth increments, periodicity, sclerochronology, Paracas Bay

\section{Introduction}

The Peruvian scallop, Argopecten purpuratus (Lam., 1819), is a hermaphrodite pectinid bivalve, that occurs mainly along the Pacific coast of Peru and northern Chile (Wolff and Mendo, 2000) in semi-protected coastal and island bays with soft bottom sediment (Brand, 1991). Expansion of A. purpuratus stocks in southern Peru, especially near Pisco during El Niño events of 1982-83 and 1997-98, contributed to the intensive exploitation of this resource for export purposes. In the last decade, bottom and suspended cage aquacultures have gradually replaced fishing of the Peruvian scallop. Scallop has become the major aquaculture activity along the Peruvian coast. Paracas Bay represents a major traditional cultivation and fishing area of the Peruvian scallop especially during El Niño events.

This activity has catalyzed widespread studies of A. purpuratus stocks along the Peruvian and Chilean coasts (see e.g. Wolff, 1987; Yamashiro and Mendo, 1988; Alarcon and Wolff, 1991; Mendo and Jurado, 1993) that demonstrate significant spatial and temporal variability in growth. Several studies relate temporal variability in the growth of this species to environmental conditions induced by El Niño Southern Oscillation (ENSO) (Wolff, 1987; Mendo and Wolff, 2003; Thébault et al.,

${ }^{*}$ Corresponding author : J. Flye-Sainte-Marie ; email: flye@ univ-brest.fr
2008). Most of these studies are based on a cohort growth monitoring rather than high-frequency individual growth surveys (Thébault et al., 2008). In spite of these studies, the links between short-term growth and environmental parameters (e.g. physico-chemical parameters of seawater, temperature, trophic resource availability/quality) remain poorly known.

Shell growth striae on the surface of many scallops, including A. purpuratus, offer a mechanism for high-frequency monitoring of individual growth in bivalves. Although most studies show daily formation of shell striae formation in the genera Argopecten (Wrenn, 1972; Clark, 1975; Helm and Malouf, 1983) and Pecten (Clark, 1968, 1975; Antoine, 1978; Chauvaud et al., 1998; Chauvaud, 2005) some evidence suggests a 2-day periodicity in the tropical scallop Comptopallium radula (Thébault et al., 2005), demonstrating that periodicity must be determined prior to any sclerochronological study. Knowledge of this rhythm allows use of inter-striae distances to determine the growth rate per unit time and evaluation of the relationship between growth rate and environmental conditions. Chauvaud et al. (1998) demonstrated the potential of daily striae for relating growth and environmental variables in P. maximus.

The objectives of our study are (1) to determine the periodicity of shell striae formation in A. purpuratus and (2) to investigate the influence of environmental parameters on its growth rate in Paracas Bay. We also evaluate the different farming sys- 
tems of the Peruvian scallop and their consequences in terms of growth.

\section{Material and methods}

\subsection{Scallop collection and shell marking}

The scallops were collected as post-larvae in Samanco Bay using commercial collectors and were maintained suspended in the water column in cultivation lanterns (pearl nets) and remained until they reached $\approx 25 \mathrm{~mm}$ average shell height $(H)$. Scallops then were transported in refrigerated seawater $\left(\approx 10^{\circ} \mathrm{C}\right)$ to the Paracas Bay experimental site where they were placed on the bottom in a 7-m depth area devoted to commercial farming

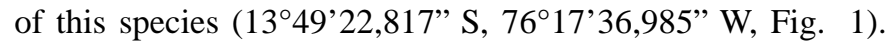
The interruption of growth caused by the stress of transport left a visible mark on the valves in all individuals. Scallops were kept undisturbed in the field to acclimate for 60 days before starting the experiment.

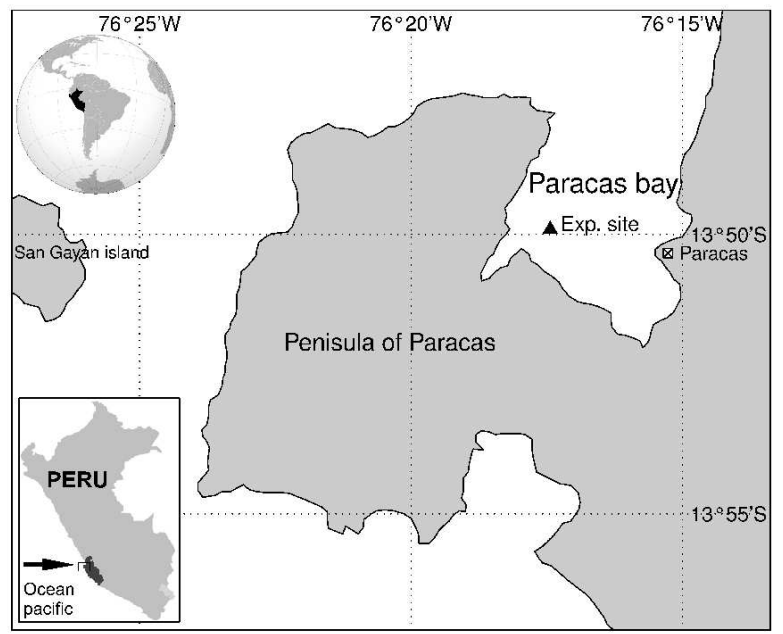

Figure 1: Map of the experimental site in Paracas Bay (Peru; 1349’22,817'” $\left.\mathrm{S}, 76^{\circ} 17^{\prime} 36,985^{\prime} \mathrm{W}\right)$. The experimental site was located in a $7 \mathrm{~m}$-deep area dedicated to commercial farming of Argopecten purpuratus.

\subsection{Monitoring of growth}

By the end of the acclimation period scallops reached a size of $35-45 \mathrm{~mm}$. We monitored growth periodically during the 98 days between April and July 2007. Over this period, we exposed the scallops to two contrasting growing conditions. Individuals were randomly arranged at a density of 30 individuals per cage within 14 circular cages constructed of a metallic frame and monofilament nylon mesh (diameter $=50 \mathrm{~cm}$, height $=20 \mathrm{~cm})$. Seven cages were placed on the bottom in contact with the sediment (bottom treatment) while the others were suspended at $2 \mathrm{~m}$ above the bottom (suspended treatment; Fig. 2). Every 14 days, scallops were sampled by removing one cage from bottom and suspended treatments and selecting three or four individuals per cage excluding damaged or heavily fouled individuals. The tissues were completely removed from the shells and valves were dried and stored for subsequent striae measurement.

\subsection{Monitoring of environmental variables}

We measured physico-chemical descriptors of seawater at the depth of each treatment. Temperature was measured with two data-loggers that recorded one datum every hour. Dissolved oxygen and salinity were measured using a multi-parameter sensor HACH (HQ40D) two days per week, in the morning (6 a.m.) and in the afternoon (2 p.m.). Simultaneously, current velocity was measured with a propeller current-meter. Concentrations of chlorophyll- $a$ and phaeopigments were measured two days per week from samples collected in the morning and afternoon. For this purpose, we filtered $100 \mathrm{~mL}$ of seawater from the sediment-water interface and from the water column at two meters above the bottom through filter $\mathrm{GF} / \mathrm{F}(0.7 \mu \mathrm{m}$ pore size). Photopigments were extracted for $24 \mathrm{~h}$ in $10 \mathrm{~mL}$ of acetone $90 \%$ and quantified with a fluorometer (TURNER AU10). Particulate organic material was collected using two sediment traps deployed weekly for $48 \mathrm{~h}$ at depths corresponding to each treatment (Fig. 2). Trapped material was lyophilized and the particulate organic carbon and nitrogen (POC and PON respectively) quantities were determined with a $\mathrm{CHN}$ elemental analyzer (EuroEA). Finally, the mean concentrations of POC and PON in the environment were calculated following Armanini and Ruol (1988) and assuming a sinking velocity of $4.167 \mathrm{~m} \mathrm{~h}^{-1}$ for the sediment, based on diatom data (Alldredge and Gotschalk, 1989).

$$
C=\frac{M}{(w \cdot A \cdot \Delta t)} x 1000 \mathrm{mg} \mathrm{L}^{-1}
$$

with:

$C$ : POC or PON concentrations $\left(\mathrm{mg} \mathrm{L}^{-1}\right)$

$M$ : mass of trapped material (mg)

$w$ : settling velocity of the sediment particles $\left(\mathrm{m} \mathrm{h}^{-1}\right)$

$A$ : srea of the collection orifice of the trap $\left(\mathrm{m}^{2}\right)$

$\Delta t:$ deployment time (h)

\subsection{Shell preparation and observation}

Although striae are more visible in the left valves, preliminary trials indicated that fouling would often prevent a complete reading along the maximum growth axis and we therefore performed striae measurement on right valves (Fig. 3). The selected valves of $A$. purpuratus were first cleaned with fresh water and immersed in glacial diluted acetic acid for $30 \mathrm{~s}$ to remove any fouling. Valves were then rinsed thoroughly and dried before they were encased in polyester resin (SODY 33R). After the resin hardened, valves were sectioned along the dorsoventral axis, parallel to the central rib, using a low-speed diamond saw (Struers Accutom 50). Sections were grounded and polished to reveal external striae in cross-section. Photographs were taken under a binocular microscope at $\times 20$ for the counting of striae and measurement of the interstriae distances as well as umbo-striae distances. In order to determine the rhythm of striae formation, we performed a linear regression (ordinate origin forced to zero) of the number as a function of the number of days between the transport date $\left(\mathrm{t}_{\text {initial }}=\right.$ stress mark) and the collection date. 


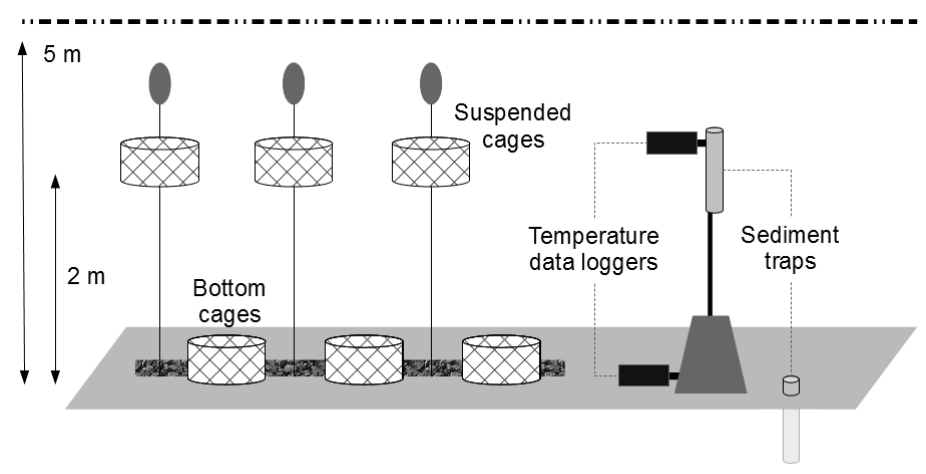

Figure 2: Experimental set-up for the scallop cultures (suspended and bottom) and measurement of environmental parameters.

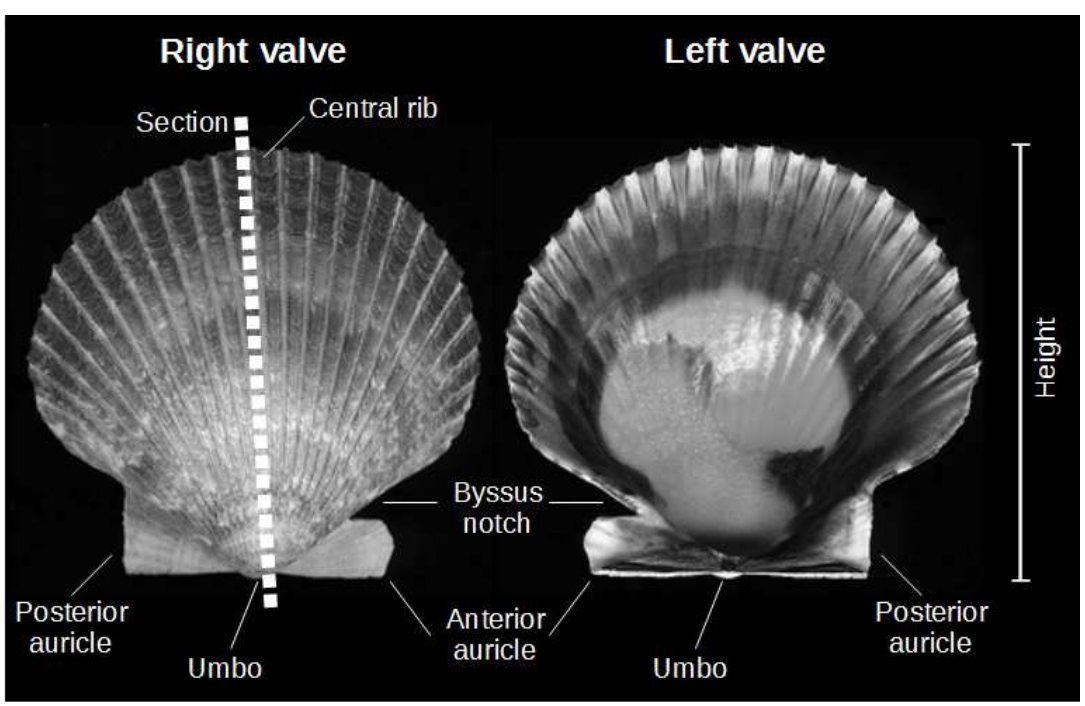

Figure 3: Morphology of A. purpuratus valves. The Peruvian scallops rest on their right valve, Sections for the study of striae were performed parallel to the valve central rib in as shown in figure.

\subsection{Growth modeling and data analysis}

Because A. purpuratus typically lives on the sediment striae and many striae readings were available, we considered individual growth in the bottom treatment as a reference in order to study the influence of environmental variables. In addition, published growth parameters were available for bottom-living individuals in Paracas Bay. The von Bertalanffy's growth function (VBGF) was adjusted to the observations:

$$
H_{t}=H_{\infty} \cdot\left(1-e^{-K\left(t-t_{0}\right)}\right)
$$

with:

$H_{t}:$ shell height at time $\mathrm{t}(\mathrm{mm})$

$H_{\infty}$ : asymptotic shell height $(\mathrm{mm})$

$K$ : growth coefficient (year ${ }^{-1}$ )

$t_{0}:$ age when shell height equals zero (years)

For this purpose, we fixed $H_{\infty}$ at $110 \mathrm{~mm}$ according to Wolff (1987) and calculated $K$ according to the linearized method suggested by von Bertalanffy (1934):

$$
-\ln \left(1-H_{t} / H_{\infty}\right)=-K . t_{0}+K . t
$$

For both treatments, we calculated shell microgrowth rates for height ( $G R, \Delta H / \Delta t \mu \mathrm{m} /$ day $)$. In order to remove the natural reduction of growth with size/age (Gulland and Hold, 1959) we adopted the following methodology: for each treatment, we calculated deviations $(E)$ between the observed growth rate and the calculated growth rate expected from adjusted VBGF for bottom individuals $\left(G R^{\text {calc.bottom }}\right)$ as follows :

$$
E_{t}=\bar{X}_{t}-G R_{t}^{\text {calc.bottom }}
$$

with:

$E_{t}=$ growth rate deviation $\left(\mu \mathrm{m} \mathrm{d}^{-1}\right)$ at time $\mathrm{t}$

$X_{t}=$ observed average growth rate at time $\mathrm{t}$

$G R_{t}^{\text {calc.bottom }}=$ Calculated bottom growth rate at time $\mathrm{t}$ (from VBGF)

We also calculated the daily average temperature and weekly averages for the other environmental variables. Analysis of 
time series of height growth rate deviations $(E)$ and environmental parameters for the bottom was conducted using crosscorrelation function analysis (CCF) to highlight possible correlations at time $\mathrm{t}$ and with a time offset $(\mathrm{t}-\mathrm{h})$. All data treatment and statistical analyses were performed with $\mathrm{R}$ software ( $\mathrm{R} \mathrm{De}-$ velopment Core Team, 2009)

\section{Results}

\subsection{Periodicity of micro-growth striae formation}

The stress mark produced during transport was clearly visible on all studied valve sections, showing clear interruption of growth (calcification; Fig. 4). Subsequent growth produced an observable discontinuity on valves. Only post-stress striae were visible because abrasion of the shell surface obliterated older striae. We were able to analyze a total of 17 valves from the bottom treatment and 13 from the suspended treatment. The number of growth days (days between stress date and collection date) showed a strong linear relationship with the number of striae $\left(\mathrm{R}^{2}=0.9979, p<0.001\right)$ and a slope of 1.003 striae/day (Fig. 5). Differences between treatments were not significant $(p>0.05)$. The slope estimated for the combined individuals did not differ significantly from 1 stria/day $(p>0.05)$. For the last bottom treatment sampling we observed two individuals outside the regression's forecasting confidence interval.

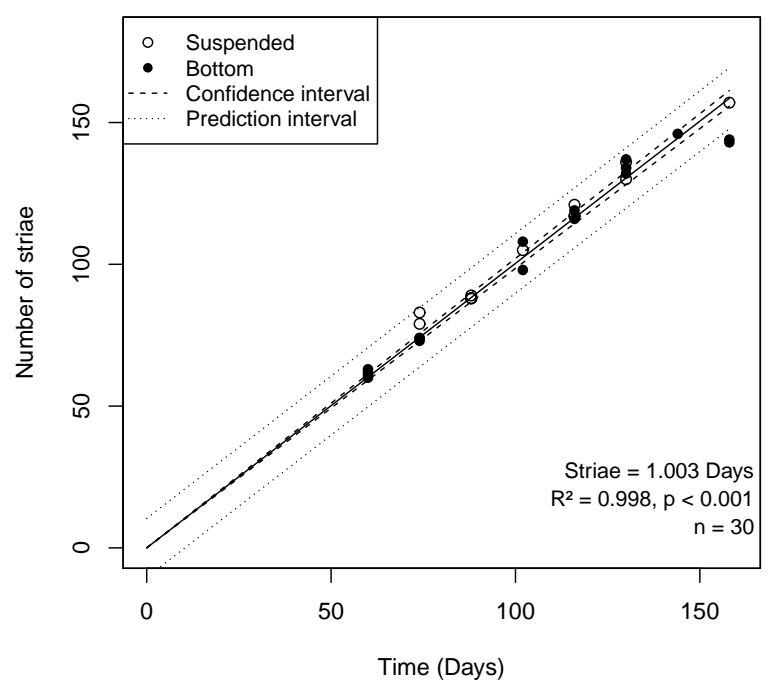

Figure 5: Relationship between the number of striae counted from the stress mark to the ventral margin of the shell and the number of days between the transport and collection date for scallops from bottom and suspended treatments.

\subsection{Temporal variation of height microgrowth rates}

Next, we considered the difference in height between two striae $\left(H_{t+1}-H_{t}\right)$ by height daily microgrowth increment, and we observed a low inter-individual variability of average microgrowth rates (Fig. 6): $\approx 30 \mu \mathrm{m} \mathrm{d}^{-1}$ on average and rarely exceeding $100 \mu \mathrm{m} \mathrm{d}^{-1}$. For the bottom treatment, we show all post stress measurements, whereas for the suspended treatment we report increments from day 60, when individuals were placed in suspension. Fitting a VBGF to the data for the bottom treatment, with $H_{\infty}$ fixed to $110 \mathrm{~mm}$, gives a value of $K=1.44\left(\mathrm{R}^{2}\right.$ $=0.875, p<0.001$, see Fig. 6). Deviations from $G R^{\text {calc.bottom }}$ were higher in the suspended than in the bottom treatment, especially around days $65,80,130$ and 140 . In the bottom treatment, we observed negative deviations especially in the days prior to the beginning of the experiment (day 60) and around day 75. However, variations in growth rates remained fairly synchronized between the two treatments, except for the last 15 days, where growth suddenly increased in the suspended treatment.

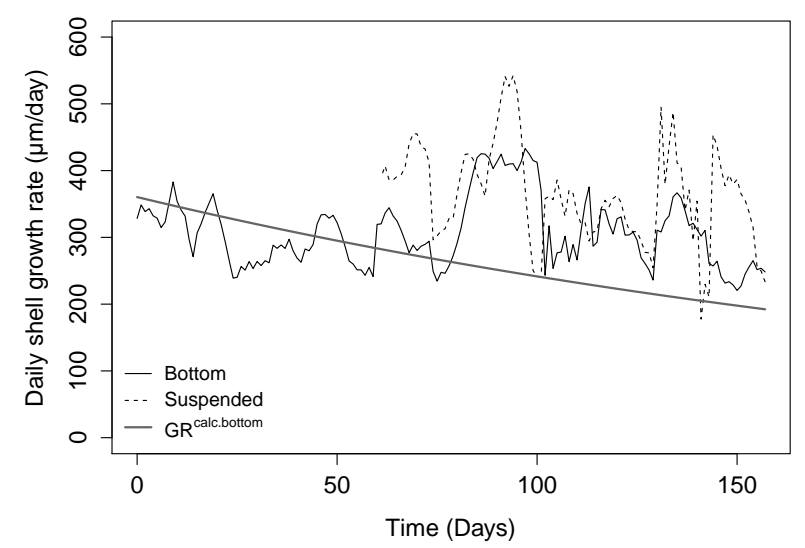

Figure 6: Temporal variations in average daily microgrowth rate $\left(\mu \mathrm{m} \mathrm{d}^{-1}\right)$ for scallops in bottom and suspended treatments. For scallops in bottom treatment, the entire post-stress measurements are shown. For suspended treatment the series starts at day 60 , when the individuals were placed in suspension. Stronger gray line indicates growth rate calculated from VBGF for bottom individuals $\left(G R^{\text {calc.bottom }}\right)$.

\subsection{Temporal evolution of environmental variables}

During the experiment, temperature ranged from $14.6^{\circ} \mathrm{C}$ to $22.6^{\circ} \mathrm{C}$ (Fig. 7 a). Bottom and the suspended treatments exhibited similar temperature variation, although temperature in the suspended treatment was approximately one-tenth of a degree higher than in the bottom treatment. Temperature also varied daily of approximately $1^{\circ} \mathrm{C}$; and we sometimes observed sharp temperature variations, reaching $4^{\circ} \mathrm{C}$ per day. Oxygen saturation (Fig. $7 \mathrm{~b}$ ) varied between $4.2 \%$ and $128.2 \%$ in the bottom treatment and from $14.3 \%$ to $138.6 \%$ in the suspended treatment. For both treatments, we consistently observed lower values at 6 a.m. and higher values were at 2 p.m (Fig. 8 a). Current speed (Fig. $7 \mathrm{c}$ ) also exhibited daily variations with low values (close to $0 \mathrm{~cm} \mathrm{~s}^{-1}$ ) during the morning and higher values in the afternoon (Fig 8b). The maxima observed were $35 \mathrm{~cm} \mathrm{~s}^{-1}$ in bottom and $50 \mathrm{~cm} \mathrm{~s}^{-1}$ in suspended treatments. Average current speed was significantly higher in the suspended than in the 


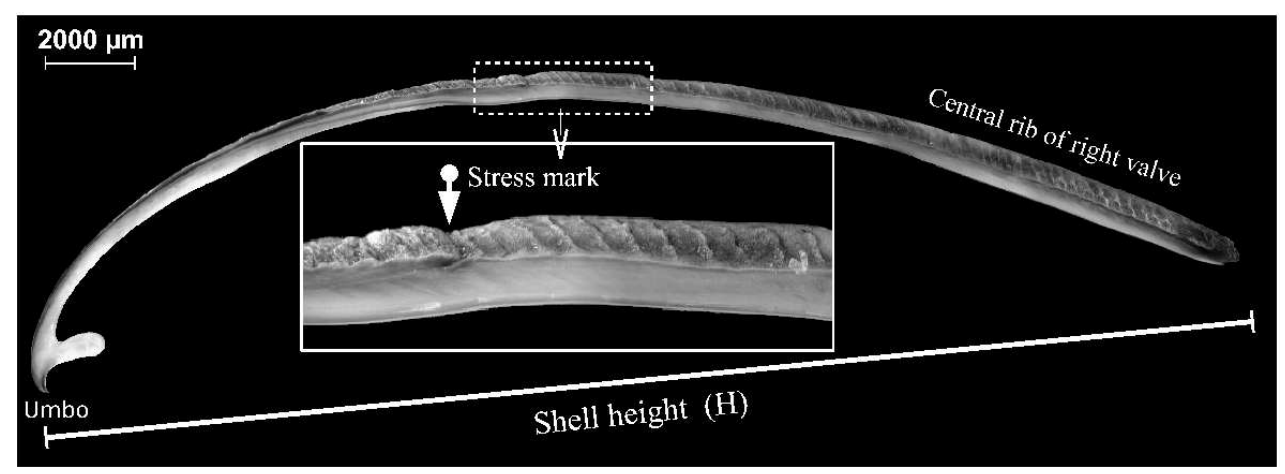

Figure 4: Right valve section view along the dorso-ventral maximum growth axis (height, H), parallel to the central rib. The inset shows a detail of a shell section. Reference stress mark (caused by transport of scallops to the experimental site in Paracas Bay) and striae are visible.

bottom treatment $(p<0.05)$. Salinity varied between 29.2 and 37.5 in both treatments (Fig $7 \mathrm{~d}$ ), with minima during the first two weeks; after this period salinity remained almost constant for the duration the experiment.

POC concentrations (Fig. $7 \mathrm{~g}$ ) varied between 0.853 and $3.714 \mathrm{mg} \mathrm{L}^{-1}$ in the bottom treatment and between 0.811 and $3.166 \mathrm{mg} \mathrm{L}^{-1}$ in the suspended treatment. POC peaked around days 90 and 150 in the bottom treatment and around days 100 and 150 in the suspended treatment. POC evolution in the two treatments showed similar patterns except around day 30 when POC concentrations were much higher in the bottom than in the suspended treatment. PON levels (Fig. $7 \mathrm{~h}$ ) ranged between 0.140 and $0.482 \mathrm{mg} \mathrm{L}^{-1}$ in the bottom treatment and between 0.128 and $0.446 \mathrm{mg} \mathrm{L}^{-1}$ in the suspended treatment; the overall pattern of variation paralleled that observed in POC concentrations. PON concentrations peaked around days 40 and 90 at both depths, but were higher in the bottom than in the suspended treatment. We observed low concentrations of POC and PON during the first four weeks of monitoring.

Chlorophyll- $a$ peaked twice during the experimental period: first between days 60 and 70 in the bottom treatment only and again between days 110 and 115 in both treatments. Minimum concentrations occurred around days 80 and 145 for both treatments. In the suspended treatment, phaeopigment concentrations were almost constant and relatively low in contrast to very high values recorded between days 100 and 115 . Phaeopigment concentration minima occurred for the two treatments around day 75. Phaeopigment concentration differed significantly between treatments $(p<0.05)$ but chlorophyll-a concentration did not.

\subsection{Environmental influence on microgrowth increments}

The CCF analysis in this section (Tab. 1 ) only considers negative time-lags $(\mathrm{h})$ because this approach correlates environmental variables at time $\mathrm{t}$ or $\mathrm{t}$-h with growth rate deviations $E$ at time t. We studied $E$ from bottom and suspended treatments ( $E_{\text {bottom }}$ and $E_{\text {suspended }}$ respectively) in relation to temperature at daily resolution and other environmental parameters were at weekly resolution to correspond to the timing of acquisition of environmental data.

Environmental parameters correlated significantly with $E$ from bottom and suspended treatments at different time-lags
(Table 1). The $E_{\text {bottom }}$ correlates significantly and negatively negative correlations with temperature and currents at specific time-lags ( $>-7$ days). The availability of trophic resources, measured as concentrations of POC and PON, correlated positively with no time-lag. In the case of the $E_{\text {suspended }}$, only temperature correlated significantly (with a significant time-lag) but with a small CCF coefficient.

A significant linear regression $(p<0.01)$ indicates that POC explained $39.8 \%$ of the variation of $E_{\text {bottom }}$.

Table 1: Summary of significant CCF correlations found between growth rate deviations in bottom $\left(E_{\text {bottom }}\right)$ and suspended ( $\left.E_{\text {suspended }}\right)$ treatments as a function of environmental parameters. Only negative time-lags (h) are studied. Given the periodicity of environmental data acquisition, we studied lags for temperature at a daily resolution as opposed to a weekly resolution for other environmental parameters.

\begin{tabular}{lcccc}
\hline & \multicolumn{2}{c}{$E_{\text {bottom }}$} & \multicolumn{2}{c}{$E_{\text {suspended }}$} \\
& Max. CCF* & h (-) & Max. CCF* & h (-) \\
\hline Temperature & -0.425 & 10 days & -0.270 & 12 days \\
Oxygen saturation & - & - & - & - \\
Salinity & - & - & - & - \\
Current & -0.607 & 1 week & - & - \\
Chlorophyll-a & - & - & - & - \\
Phaeopigments & - & - & - & - \\
POC & 0.631 & 0 weeks & - & - \\
PON & 0.583 & 0 weeks & - & - \\
\hline
\end{tabular}

*Significant at $\alpha=0.05$

\section{Discussion}

\subsection{Periodicity of microgrowth striae formation}

The close relationship between the number of striae and the number of days since the stress mark - with a slope of 1 - clearly indicates a daily formation of shell microstriae in $A$. purpuratus at Paracas Bay, which confirms the assumption of Thébault et al. (2008) and estimation of Gosselin et al. (2013) based on recorded seawater temperature variations for this species. This daily striae formation rhythm confirms results obtained for most other species of Argopecten. Such a rhythm has been suggested for Argopecten irradians (Wrenn, 1972; Clark, 1975; Wheeler et al., 1975; Helm and Malouf, 1983), Argopecten gibbus and Argopecten circularis (Clark, 1975) as 

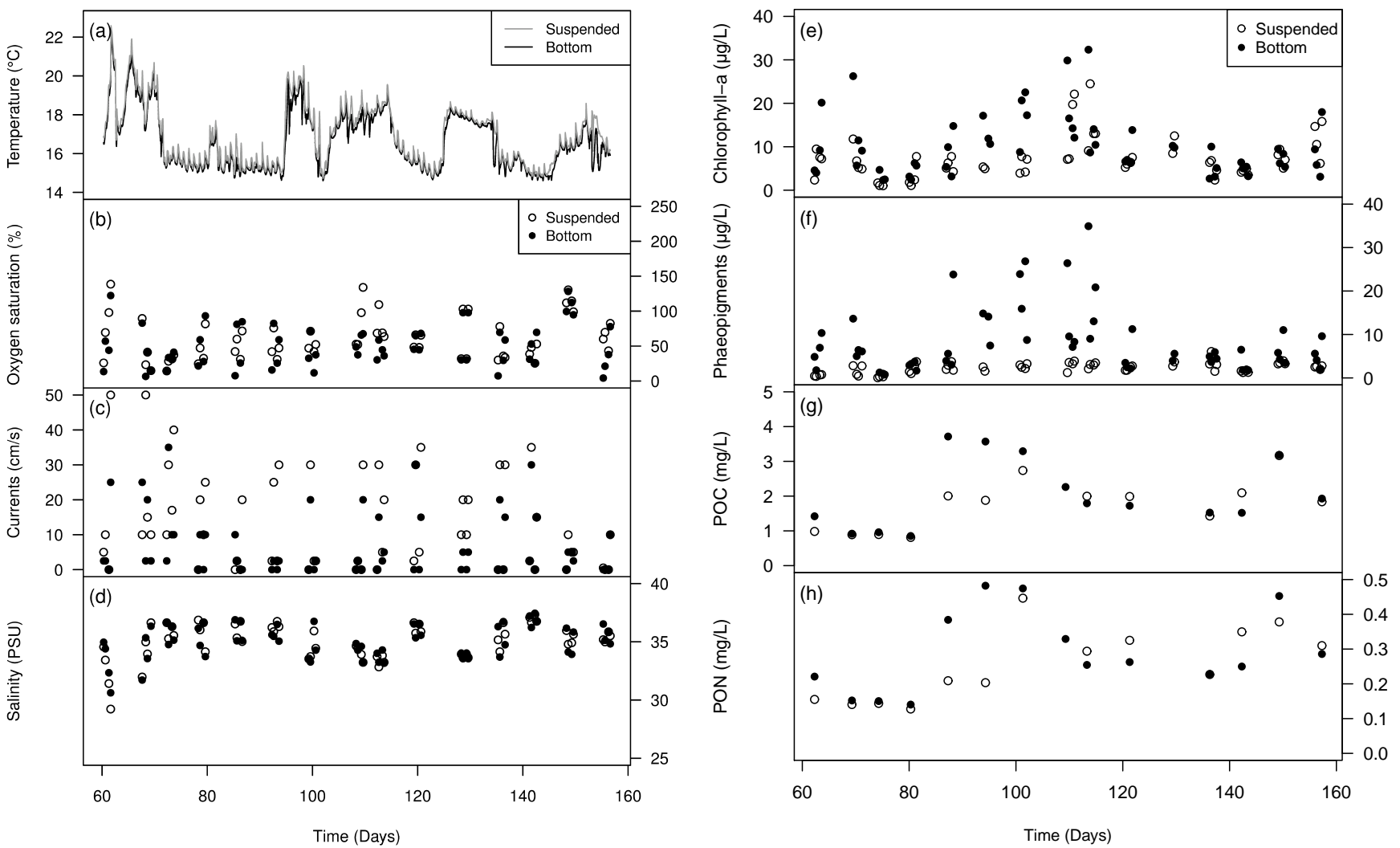

Figure 7: Temporal variation in (a) temperature, (b) dissolved oxygen saturation, (c) currents, (d) salinity, (e) chlorophyll-a concentration, (f) phaeopigments, (g) particulate organic carbon (POC) concentration and, (h) particulate organic nitrogen (PON) concentration in bottom and suspended treatments.
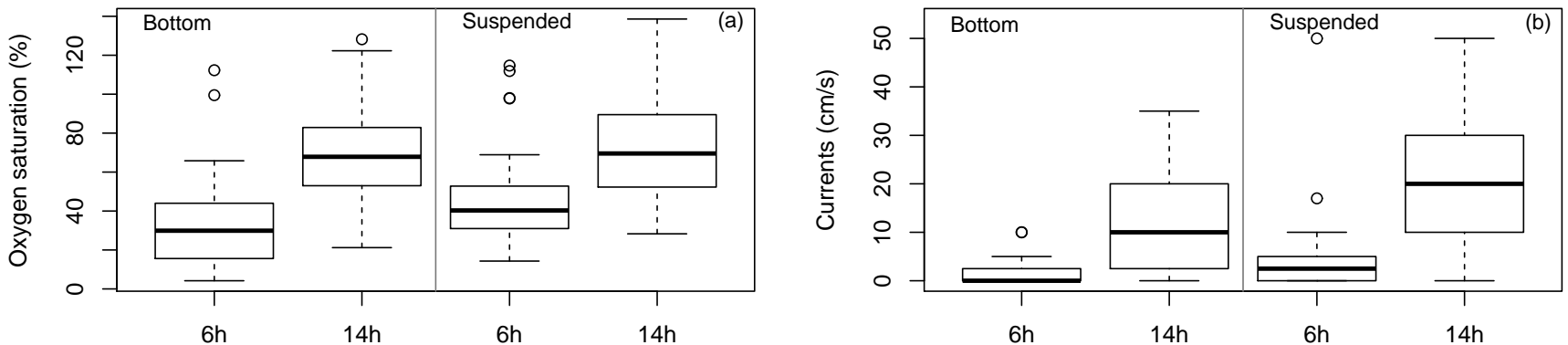

Figure 8: Daily variation (morning and afternoon measurements) in (a) dissolved oxygen saturation and (b) currents in bottom and suspended treatments. Open circles represent outlier values.

well as other Pectinidae species including juveniles of Pecten diegensis (Clark, 1968), Pecten vogdesi, (Clark, 1975) Chlamys opercularis (Broom and Mason, 1978) and Amusium balloti (Joll, 1988), juveniles and adults of Pecten maximus (Antoine, 1978; Chauvaud et al., 1998; Owen et al., 2002) and larvae and post-larvae of Placopecten magellanicus (Hurley et al., 1987; Parsons et al., 1993). Photoperiod presumably controls this daily periodicity (Clark, 2005).

However, a recent study carried out in the protected marine area of La Rinconada, Chile, indicates a deposition of one strium every two days in adult individuals of A. purpuratus marked with calcein and measured over 140 days (Thouzeau, personal communication). Rhythmic activities are generally assumed to be controlled by endogenous oscillators synchronized by environmental cues acting as zeitgebers (Aschoff et al., 1982). In marine bivalve striae formation corresponds to a growth rate decrease brought about by altered metabolism (Chauvaud et al., 1998). Diurnal, tidal and seasonal environmental cycles are known to drive growth rhythms (Rosenberg and Jones, 1975). Confirmation of Thouzeau's results would strongly suggest that different zeitgebers synchronize and/or control metabolic rhythms of scallops from the Paracas Bay and from La Rinconada populations. However, reports of 2-day long biological rhythms in nature are unusual. Only Mercenaria merce- 
naria (Pannella and MacClintock, 1968; Kennish and Olsson, 1975) and Comptopallium radula (Thébault et al., 2005) were reported to exhibit such a 2-day periodicity of microstriae formation.

In the case of Paracas Bay, rhythm synchronized to the tidal cycle (mixed regime predominantly semidiurnal) is unlikely given the small amplitude $(<1 \mathrm{~m})$ in this area. We can also eliminate the daily increase in turbidity resulting from wind-driven turbulence in the water-sediment boundary layer (weak in the morning to strong in the afternoon) as the cause given that the rhythm in suspended scallops, without resuspended sediment particles, was no different. Daily changes in oxygen saturation seem a much more likely driver of periodicity in growth. The low saturation values observed at 6 a.m. (average of 30 $\%$ in bottom and $40 \%$ in the suspended treatment) confirm nocturnal hypoxia. Oxygen availability is a key regulator of metabolic processes of marine invertebrates. Aquatic organisms may respond to hypoxia by (1) attempting to maintain oxygen delivery, (2) reducing energy expenditure, and (3) enhancing energetic efficiency and deriving energy from anaerobic sources (Wu, 2002). Bivalves may reduce their metabolic rate in response to hypoxia (Storey and Storey, 2004). This reduced-oxygen stress could stop shell growth during the night, but growth could resume during the day when oxygen saturations are more favorable, thus creating a circadian rhythm as an energetic strategy to cope with high variations in oxygen availability. In the Pectinidae family, particularly in temperate zones, long-term growth deceleration (Krantz et al., 1984; Owen et al., 2002) or even growth cessations occurred during winter. Although our study only integrates a 160-day period between February and July 2007, the periodicity observed during the monitoring likely persists throughout the year given the reduced seasonality in the Paracas Bay area and a year round high primary production is supported by consistent upwelling. However, decreased striae deposition rate occurs in older aged individuals, as in P. maximus (Antoine, 1978).

\subsection{Influence of environmental parameters on microgrowth in- crements}

The positive effect of POC and PON on bottom growth rates found in our study study contradicts the results of Thébault et al. (2008) who hypothesized that an increase in POC concentration above a threshold of $2.5 \mathrm{mg} \mathrm{L}^{-1}$ might affect growth negatively. A negative effect of sedimentation of high amounts of organic particles was also suggested for P. maximus (Chauvaud et al., 1998; Lorrain et al., 2000; Chauvaud et al., 2001). Nevertheless, we observed no negative effect with concentrations of POC comparable to those measured by Thébault et al. (2008) (between 1 and $4 \mathrm{mg} \mathrm{L}^{-1}$ ). Perhaps inhibited filtration at high concentrations of POC and PON relates to the size and rate of agglomeration and origin of the particles (e.g. phytoplankton, detrital).

Food availability was apparently higher for scallops living on the bottom in our experiment. Nevertheless, growth rates in suspended scallops were considerably higher in several periods of the study. It is possible that the food availability descriptors that we measured miss certain aspects of seston quality and composition (phytoplankton/detritus/particulate inorganic material) that primarily determine growth. The energy balance of adult A. purpuratus depends strongly on diet composition (Navarro et al., 2000) and many laboratory studies show strong effects of food composition and quality on juvenile growth (Diaz and Martinez, 1992; Martinez et al., 1995; Uriarte and Farias, 1999) and fertility in A. purpuratus adults (Farias and Uriarte, 2001). The presence of abundant phaeopigments on the bottom, which was the only measured trophic descriptor that differed significantly between the two treatments, might indicate reduced food quality because these molecules reflect degradation/digestion of chlorophyll.

Inhibition of filtration by high currents, as has been observed in other bivalve species such as P. magellanicus (Wildish et al., 1992; Pilditch and Grant, 1999) could explain the negative effect of current velocity observed in our study. In addition, high currents might increase sediment resuspension at the water-sediment interface, which could increase turbidity, resulting in a decreased feeding activity and therefore growth (Sobral, 2000). Furthermore, currents in Paracas Bay are generated almost exclusively by offshore winds, which transport particulate inorganic matter from the adjacent desert. This material might contribute to a degradation of the quality of available seston, and consequently affects scallop feeding. Negative effects of high particulate inorganic matter on bivalve nutrition are well known (see Widdows et al., 1979). In the Paracas Bay environment, particulate inorganic matter spikes could last for several days after a windy event (sandstorm type), which could explain the one week time-lag in our correlation.

Temperature has often been identified as a key regulator of scallop growth (Broom and Mason, 1978; Wilson, 1987; Chauvaud et al., 1998; González et al., 1999; Laing, 2000; Wallace and Reinsnes, 1985; Macdonald and Thompson, 1986). Previous studies in the Paracas area indicated a positive effect of temperature on populations of A. purpuratus (Mendo and Jurado, 1993; Mendo and Wolff, 2003). However, depending on the period of year and the cohort, Wolff (1987) observed positive and negative relationships between temperature and growth rates. Thébault et al. (2008) recognized that temperature produced a significant positive effect on A. purpuratus shell growth in La Rinconada Marine Reserve, Chile. However, two hypotheses could explain the significant negative relationship in our study. The first is that temperature that exceeds the upper limit of the species' thermal tolerance results in reduced growth (e.g. during an El Niño event; Urban, 1994). However, the relatively low temperature (rarely exceeding $20^{\circ} \mathrm{C}$ ) during our study period precludes this explanation. Although A. purpuratus acclimates well metabolically to temperature $\left(10^{\circ} \mathrm{C}-18^{\circ} \mathrm{C}\right.$ González et al., 2002) rapid initiation of warm periods could adversely affect growth (up to $4^{\circ} \mathrm{C} /$ day as indicated by the temperature record), by causing metabolic stress (Peck et al., 2009). The observed correlation time-lags ( -10 and -12 days in bottom and suspended respectively) mirror the 6.3 days time-lag reported by Gosselin et al. (2013) between sclerochronological and the seawater temperature series at la Rinconada, Chile, which the authors attribute to a growth stop. Nevertheless temperature could potentially affect diverse metabolic processes simultane- 
ously (Kooijman, 2010) and growth consequences might not be observable instantaneously at a daily resolution. In this context, temperature increase can also affect gametogenesis and spawning (not included in this study) (Barber and Blake, 2006) compromising the energy available for scallop growth, since these processes demand high energy in bivalves (Sastry, 1979)

The methodology adopted to evaluate the influence of environmental parameters on growth, using deviations from VBGF, has been shown to correct for effects of age (Thébault et al., 2008). Similarly, cross-correlation analysis revealed correlations and allowed us to highlight time-lagged relationships. These time lags are presumably driven by metabolic smoothing and/or delaying of environmental variability impact on growth.

\section{Conclusion}

The stress generated by transport caused a visible mark on valves of A. purpuratus. This mark allowed us to demonstrate daily rhythm of striae formation in Peruvian scallop in Paracas Bay. This information allows precise age determination for stock evaluation and productivity and management studies. It also opens the possibility of using growth-increment information alongside stable isotope and microelement data for environmental reconstructions (e.g. for El Niño events).

Environmental variables affect growth in complex ways. Evaluation of food quality, composition (e.g. species of phytoplankton, detritus type) and form (e.g. degree of aggregation) is necessary since classical food descriptors cannot adequately growth differences between bottom and suspended scallops. Importantly, growth responses to changing environmental conditions are not always instantaneous, likely because of time-lags induced by metabolic processes (e.g. digestion, use/movements of reserves, growth, reproduction). Development of bio-energetic models might be particularly helpful in addressing these questions.

\section{Aknowledgments}

We thank the Faculty of Fishery of the Universidad Nacional Agraria La Molina for providing the logistical means to realize this study at Paracas Bay. We also thank the staff of the sclerochronolgy team of the "LASAA" who helped in the sclerochronological preparation of samples. We are grateful for the valuable contributions of the two anonymous reviewers and of Dr. Paul Snelgrove on the publication of this paper. This work is part of a PhD thesis supported by IRD within the framework of LMI-DISCOH and have been supported by LabexMER.

\section{References}

Alarcon, E., Wolff, M., 1991. Estudio biológico pesquero sobre el recurso de ostiones (Argopecten purpuratus) de Bahía Tongoy, Primera Etapa. Informe Final 1990-1991. Tech. rep., Universidad Católica del Norte, Coquimbo, Chile.

Alldredge, A., Gotschalk, C., 1989. Direct observations of the mass flocculation of diatom blooms: characteristics, settling velocities and formation of diatom aggregates. Deep Sea Res. Part A. Oceanogr. Res. Pap. 36, 159-171.
Antoine, L., 1978. La coissance journalière chez Pecten maximus (L.) (Pectinidae, Bivalvia). Haliotis 9, 627-636.

Armanini, A., Ruol, P., 1988. Non-uniform suspended sediments underwaves. In: Lugo, V. (Ed.), Proceedings of the International Conference on Coastal Engineering, $\mathrm{N}^{\mathrm{o}}$ 21. Torremolinos, Spain, pp. 1129-1139.

Aschoff, J., Daan, S., Honma, K., 1982. Zeitgeber, entrainment, and masking: some unsettled questions. In: Aschoff, J., Daan, S., Gross, G. (Eds.), Vertebrate circadian system (structure and physiology), Springer, Berlin Heidelberg New York Edition. pp. 13-24.

Barber, B., Blake, N. J., 2006. Reproductive physiology. In: Shumway, S. E., Parsons, G. J. (Eds.), Developments in aquaculture and fisheries science, scallops: biology, ecology and aquaculture, Elsevier, Amsterdam Edition. pp. 357-416.

Brand, A. R., 1991. Scallop ecology: distributions and behaviour. In: Shumway, S. E. (Ed.), Scallops: biology, ecology and aquaculture, Elsevier, Amsterdam Edition. pp. 517-584.

Broom, M. J., Mason, J., 1978. Growth and spawning in the pectinid Chlamys opercularis in relation to temperature and phytoplankton concentration. Mar. Biol. 47, 277-285.

Chauvaud, L., 2005. Shell of the Great Scallop Pecten maximus as a highfrequency archive of paleoenvironmental changes. Geochemistry Geophys. Geosystems 6 (8), 1-15.

Chauvaud, L., Donval, A., Thouzeau, G., Paulet, Y. M., Nézan, E., 2001. Variations in food intake of Pecten maximus (L.) from the Bay of Brest (France): influence of environmental factors and phytoplankton species composition. C.R Acad. Sci. Paris 324 (8), 743-55.

Chauvaud, L., Thouzeau, G., Paulet, Y.-M., 1998. Effects of environmental factors on the daily growth rate of Pecten maximus juveniles in the Bay of Brest (France). J. Exp. Mar. Bio. Ecol. 227 (1), 83-111.

Clark, G. R., 1968. Mollusk shell: Daily growth lines. Science 161, 800-802.

Clark, G. R., 1975. Periodic growth and biological rhythms in experimentally grown bivalves. In: Rosenberg, G., Runcorn, S. (Eds.), Growth rhythms and the history of the earth's rotation, JohnWiley \& Sons, London Edition. pp. $103-117$.

Clark, G. R., 2005. Daily growth lines in some living Pectens (Mollusca: Bivalvia), and some applications in a fossil relative: Time and tide will tell. Palaeogeogr. Palaeoclimatol. Palaeoecol. 228 (1-2), 26-42.

Diaz, M. A., Martinez, G., 1992. Efecto de diferentes dietas sobre el balance energetico de juveniles de Argopecten purpuratus L. Rev. Biol. Mar 27 (2), $163-173$.

Farias, A., Uriarte, I., 2001. Effect of microalgae protein on the gonad development and physiological parameters for the scallop Argopecten purpuratus (Lamarck, 1819). J. Shellfish Res. 20, 97-105.

González, M., Lopez, D. A., Perez, M. C., Riquelme, V. A., Uribe, J. M., Le Pennec, M., 1999. Growth of the scallop, Argopecten purpuratus (Lamarck, 1819), in southern Chile. Aquaculture 175 (3-4), 307-316.

González, M. L., Lopez, D. A., Perez, M. C., Castro, J. M., 2002. Effect of temperature on the scope for growth in juvenile scallops Argopecten purpuratus (Lamark, 1819). Aquac. Int. 10, 339-349.

Gosselin, M., Lazareth, C. E., Ortlieb, L., 2013. Sclerochronological studies in the Humboldt current system, a highly variable ecosystem. J. Shellfish Res. 32 (3), 867-882.

Gulland, J. A., Hold, S. J., 1959. Estimation of growth parameters for data at unequal time intervals. J. Cons. Inter. Exp. Mer 25, 47-49.

Helm, N., Malouf, R., 1983. Rate of production of the external ridges in the bay scallop, Argopecten irradians. Am. Zool. 23, 835.

Hurley, G. V., Tremblay, M. J., Couturier, C., 1987. Age estimation of sea scallop larvae (Placopecten magellanicus) from daily growth lines on shells. J. Northwest Atl. Fish. Sci. 7, 123-129.

Joll, L. M., 1988. Daily growth rings in juvenile saucer scallops, Amusium Balloti (Bernadi). J. Shellfish Res. 7, 73-76.

Kennish, M. J., Olsson, R. K., 1975. Effects of thermal discharges on the microstructural growth of Mercenaria mercenaria. Environ. Geol. 1, 41-64.

Kooijman, S. A. L. M., 2010. Dynamic Energy Budget theory for metabolic organisation - third edition. Cambridge University Press.

Krantz, D. E., Jones, D. S., Williams, D. F., 1984. Growth rates of the sea scallop, Placopecten magellanicus, determined from ${ }^{18} \mathrm{O} /{ }^{16} \mathrm{O}$ record in shell calcite. Biol. Bull. 167, 186-199.

Laing, I., 2000. Effect of temperature and ration on growth and condition of king scallop (Pecten maximus) spat. Aquaculture 183, 325-334.

Lorrain, A., Paulet, Y.-M., Chauvaud, L., Savoye, N., Nézan, E., Guérin, L., 
2000. Growth anomalies in Pecten maximus from coastal waters (Bay of Brest, France): relationship with diatom blooms. J. Mar. Biol. Assoc. UK 80 (4), 667-673.

Macdonald, B. A., Thompson, R. J., 1986. Production, dynamics and energy partitioning in two populations of the giant scallop Placopecten magellanicus (Gmelin). J. Exp. Mar. Bio. Ecol. 101 (3), 285-299.

Martinez, G., Caceres, L. A., Uribe, E., Diaz, M. A., 1995. Effects of different feeding regimens on larval growth and the energy budget of juvenile chilean scallops, Argopecten purpuratus Lamarck. Aquaculture 132, 313-323.

Mendo, J., Jurado, E., 1993. Length-based growth parameter estimates of the Peruvian scallop (Argopecten purpuratus). Fish. Res. 15, 357-367.

Mendo, J., Wolff, M., 2003. El impacto de El Niño sobre la produccion de concha de abanico (Argopecten purpuratus) en bahia Independencia, Pisco, Peru. Ecol. Apl. 2 (1), 51-57.

Navarro, J. M., Leiva, G. E., Martinez, G., Aguilera, C., 2000. Interactive effects of diet and temperature on the scope for growth of the scallop Argopecten purpuratus during reproductive conditioning. J. Exp. Mar. Bio. Ecol. 247, 67-83.

Owen, R., Richardson, C., Kennedy, H., 2002. The influence of shell growth rate on striae deposition in the scallop Pecten maximus. J. Mar. Biol. Assoc. UK 82 (4), 621-623.

Pannella, G., MacClintock, C., 1968. Biological and environmental rhythms reflected in molluscan shell growth. J. Paleontol. 42 (2), 64-80.

Parsons, G. J., Robinson, S. M. C., Roff, J. C., Dadswell, M. J., 1993. Daily growth rates as indicated by valve ridges in postlarval giant scallop (Placopecten magellanicus) (Bivalvia: Pectinidae). Can. J. Fish. Aquat. Sci. 50, 456-464.

Peck, L. S., Clark, M. S., Morley, S. a., Massey, A., Rossetti, H., 2009. Animal temperature limits and ecological relevance: effects of size, activity and rates of change. Funct. Ecol. 23 (2), 248-256.

Pilditch, C. A., Grant, J., 1999. Effect of variations in flow velocity and phytoplankton concentration on sea scallop (Placopecten magellanicus) grazing rates. J. Exp. Mar. Bio. Ecol. 240, 111-136.

R Development Core Team, 2009. R: A language and environment for statistical computing. R Foundation for Statistical Computing, Vienna, Austria, ISBN 3-900051-07-0.

URL http://www.R-project.org

Rosenberg, G. D., Jones, C. B., 1975. Approaches to chemical periodicities in molluscs and stromatolites. In: Rosenberg, G. D., Runcorn, S. K. (Eds.), Growth rhythms and the history of the Earth's rotation, Wiley, London Edition. pp. 223-242.

Sastry, A. N., 1979. Pelecypoda (excluding ostreidae). In: Giese, A. C., Pearse, J. S. (Eds.), Reproduction of marine invertebrates, vol. 5, Academic Press, New York Edition. pp. 113-292.

Sobral, P., 2000. Effects of increasing current velocity, turbidity and particlesize selection on the feeding activity and scope for growth of Ruditapes decussatus from Ria Formosa, southern Portugal. J. Exp. Mar. Bio. Ecol. 245 (1), 111-125.

Storey, K. B., Storey, J. M., 2004. Metabolic rate depression in animals: transcriptional and translational controls. Biol. Rev. Camb. Philos. Soc. 79 (1), 207-33.

Thébault, J., Chauvaud, L., Clavier, J., Fichez, R., Morize, E., 2005. Evidence of a 2-day periodicity of striae formation in the tropical scallop Comptopallium radula using calcein marking. Mar. Biol. 149 (2), 257-267.

Thébault, J., Thouzeau, G., Chauvaud, L., Cantillánez, M., Avendaño, M., 2008. Growth of Argopecten purpuratus (Mollusca : Bivalvia) on a natural bank in Northern Chile : sclerochronological record and environmental controls. Aquat. Living Resour. 21, 45-55.

Urban, H. J., 1994. Upper temperature tolerance of ten bivalve species off Peru and Chile related to El Niño. Mar. Ecol. Prog. Ser. 107, 139-145.

Uriarte, I., Farias, A., 1999. The effect of diatary protein content on growth an biochemical composition of Chilian scallop Argopecten purpuratus (L.) postlarvae an spat. Aquaculture 180, 119-127.

von Bertalanffy, L., 1934. Untersuchungen über die Gesetzlichkeit des Wachstums. I. Teil Allgemeine Grundlagen der Theorie: Mathematische und physiologische Gesetzlichkeiten des Wachstums bei Wassertieren. Arch. Entwicklungsmech 131, 613-652.

Wallace, J. C., Reinsnes, T., 1985. The significance of various environmental parameters for growth of the Iceland scallop (Chlamys islandica, Pectinidae) in hanging culture. Aquaculture 44, 229-242.

Wheeler, A. P., Blackwelder, P. L., Wilbur, K. M., 1975. Shell growth in the scallop Argopecten irradians. I. Isotope incorporation with reference to diurnal growth. Biol. Bull. 148, 472-482.

Widdows, J., Fieth, P., Worral, C. M., 1979. Relationships Between seston, available food and feeding activity in the common mussel Mytilus edulis. Mar. Biol. 50, 195-207.

Wildish, D. J., Kristmanson, D. D., Saulnier, A. M., 1992. Interactive effect of velocity and seston concentration on giant scallop feeding inhibition. J. Exp. Mar. Bio. Ecol. 155, 161-168.

Wilson, J. H., 1987. Environmental parameters controlling growth of Ostrea edulis L. and Pecten maximus L. in suspended culture. Aquaculture 64, 119131.

Wolff, M., 1987. Population dynamics of the peruvian scallop Argopecten purpuratus during the El Niño phenomenon of 1983. Can. J. Fish. Aquat. Sci. 44, 1684-1691.

Wolff, M., Mendo, J., 2000. Management of the Peruvian bay scallop (Argopecten purpuratus) metapopulation with regard to environmental change. Aquat. Conserv. Mar. Freshw. Ecosyst. 10 (2), 117-126.

Wrenn, S. L., 1972. Daily increment formation and synchronization in the shell of the bay scallop. Am. Zool. 12, 32.

Wu, R. S. S., 2002. Hypoxia: from molecular responses to ecosystem responses. Mar. Pollut. Bull. 45, 35-45.

Yamashiro, C., Mendo, J., 1988. Crecimiento de la concha de abanico (Argopecten purpuratus) en la Bahía Independencia, Pisco, Peru. In: Salzwedel, H., Landa, A. (Eds.), Recursos y dinamica del ecosistema de afloramiento Peruano, IMARPE Edition. pp. 163-168. 